\title{
Letter to the editor: Ongoing outbreak of dengue type 1 in the Autonomous Region of Madeira, Portugal
}

S K Ramchurn (satish.ramchurn@gmail.com) ${ }^{1}$, S S Goorah²

1. Department of Physics, Faculty of Science, University of Mauritius, Reduit, Mauritius

2. Department of Medicine, Faculty of Science, University of Mauritius, Reduit, Mauritius

Ramchurn SK, Goorah SS. Letter to the editor: Ongoing outbreak of dengue type 1 in the Autonomous Region of Madeira, Portugal. Euro Surveill. 2013;18(2):pii=20351. Available online: http://www.eurosurveillance.org/ViewArticle.aspx?Articleld=20351

To the editor: We read with great interest the article by Sousa et al. [1] in Eurosurveillance on the recent Aedes aegypti-mediated dengue fever outbreak in the Portuguese autonomous small island of Madeira. An internationally coordinated response is indeed needed in view of the challenges posed not only by this outbreak, but also by outbreaks in other islands of similar size that share characteristics like a tourism-dependent economy and vulnerability to vector-borne diseases and where, in addition, the globally expanding Ae. albopictus may be the mosquito vector of dengue viruses [2]. In this letter, we wish to highlight some similarities with the situation in Mauritius.

Mauritius is another small island which has recently suffered from outbreaks of mosquito-borne viral infections. Like Madeira, Mauritius has an influx of tourists which makes it particularly vulnerable to the entry and development of these infections. The large epidemic outbreak of chikungunya which affected about $30 \%$ of the Mauritian population in 2006 was followed by a minor outbreak of dengue fever in 2009 [3]. Ae. albopictus was the suspected mosquito-vector for both these outbreaks. Currently, Mauritius has embarked on an Integrated Vector Management (IVM) [4] strategy as part of a prevention programme targeting a number of different moquito-borne diseases. With the decreasing recourse to insecticides, IVM provides an environmentally-friendly way for the control of mosquito populations which could be particularly applicable on small islands. The precepts of IVM are advocacy, social mobilisation and legislation, collaboration within the health sector and with other sectors, an integrated approach, evidence-based decision making, and capacity building [4].

The long-term response of Madeiran authorities to the threat of dengue fever include public awareness and participation in vector control activities, and research [5]. Comparatively, the Mauritius IVM strategy is strongly community-based with a projected decentralisation of vector surveillance activities to local communities via a process of empowerment through capacity building. The implementation of the strategy relies to a great extent on the mapping and optimisation of the resources (social, economic and others) needed to ensure community participation and the sustainability of this participation.

A number of caveats have been noticed in the implementation of IVM in Mauritius. These include a slow development of programme ownership at various levels, the reliance of communities on the ability of authorities to control outbreaks, the challenges in involving nuclear families in community-based projects, and delays in providing timely incentives to participants. Despite these caveats, IVM provides a strong framework for significantly reducing the risk of vectorborne infections such as dengue fever in Mauritius and in other small islands, provided that these caveats are dealt with in a timely manner.

\section{References}

1. Sousa CA, Clairouin M, Seixas G, Viveiros B, Novo MT, Silva AC, et al. Ongoing outbreak of dengue type 1 in the Autonomous Region of Madeira, Portugal: preliminary report. Euro Surveill. 2012;17(49):pii=20333. Available from: http:// www.eurosurveillance.org/ViewArticle.aspx?Articleld $=20333$

2. Reiter P. Yellow fever and dengue: a threat to Europe? Euro Surveill. 2010;15(10):pii=19509. Available from: http://www. eurosurveillance.org/ViewArticle.aspx?Articleld=19509

3. Ramchurn SK, Moheeput K, Goorah SS. An analysis of a short-lived outbreak of dengue fever in Mauritius. Euro Surveill. 2009;14(34):pii=19314. Available from: http://www. eurosurveillance.org/ViewArticle.aspx?Articleld=19314

4. World Health Organization (WHO): Global strategic framework for Integrated Vector Management. WHO document WHO/CDS/ CPE/PVC/2004.10. Geneva: WHO; 2004. Available from: http:// whqlibdoc.who.int/hq/2004/WHO_CDS_CPE_PVC_2004_10. pdf

5. Funchal avança com plano de combate à dengue. [Funchal moves forward with plan to fight dengue]. [Accessed 3 Jan 2013]. Portuguese. Available from: http://europe.openleech.org/index.php/component/k2/ item/92463-robben-dacht-aan-stoppen. 